\title{
3
}

\section{Connecting Inquiry and Practice: Lessons Learned From a Multi-Year Professional Learning Partnership Initiative}

\author{
Carol Rolheiser, Mark Evans, Mira Gambhir, \& Kathy Broad \\ University of Toronto
}

Since 2002 the Initial Teacher Education Program at the Ontario Institute for Studies in Education, University of Toronto, has run a series of professional learning partnership projects between university instructors and K-12 educators. The Inquiry Into Practice Series, based on a collaborative inquiry approach, has strengthened the commitment to program principles and benefited the participants by deepening understanding about a range of educational questions and issues and improving practice. In this article we review key features and principles of this multi-year initiative and discuss challenges, lessons learned, and outcomes. We also provide reflections regarding the importance of high quality professional learning models that support teaching and learning and that are responsive to changing and complex educational pressures and contexts both in higher education and K-12 education.

\section{Introduction}

C urrent research indicates that teaching is becoming increasingly complex and that teachers need to continue to learn, be adaptive, build a sophisticated pedagogical repertoire, integrate different kinds of knowledge and apply emerging research for varying purposes (Bransford, Darling-Hammond \& LePage, 2005; Gopinathan et al., 2008; Halliwell, J., 2008; Turner-Bisset, 2001). Not surprisingly, there has been increasing attention to the essential role of deliberate, ongoing, high quality professional learning that is responsive to change and the challenges of today's classrooms (Berliner, 2005; Feiman-Nemser, 2001; Knight, 2011; Lieberman \& Wilkins, 2006).

Effective professional learning is viewed as essential in helping teachers unlock student potential (Broad \& Evans, 2006; Learning Forward, 2011; Ramsden, 2003). Fullan, Hill, and Crevola (2006), for example, claim that professional learning that focuses on contextually-based, personalized, inquirydriven instruction is critical to successful educational reform that will improve and sustain learning for students and teachers alike. Professional learning 
may include such approaches as study groups, action research, lesson study, online learning networks, differentiated certification and incentives, and graduate programs. While these approaches appear to have some efficacy, there is a growing consensus that other factors (e.g., context, learner differences) must be carefully considered in designing high quality professional learning.

The limited results of infrequent, poorly designed and/or inadequately delivered, often "one size fits all” approaches to teachers' professional learning, is well documented: "Nothing has promised so much and been so frustratingly wasteful as the thousands of workshops and conferences that led to no significant change in practice when teachers returned to their classrooms" (Fullan, 1991, p. 315). Those approaches to professional learning are no longer sufficient and the need for more inquiryoriented, responsive, and sustainable models is clear.

This article describes a professional learning partnership initiative implemented in a university teacher education program designed to provide university instructors and K-12 educational partners with opportunities to craft inquiry-oriented, collaborative, and contextually-based professional learning projects. This article reviews key features and principles of this multi-year initiative and discusses challenges, lessons learned, and outcomes.

\section{The Inquiry Into Practice Series}

In 2002, the Inquiry Into Practice Series was initiated by the Associate Dean of Teacher Education at the Ontario Institute for Studies in Education (OISE), University of Toronto. One of the goals was to provide meaningful professional learning opportunities for higher education teacher educators and school partners through funded projects. A related aim was to move from traditional transmission-oriented forms of professional learning to more collaborative, inquiry-oriented, sustainable approaches.

In this ongoing initiative proposals are sought from higher education instructors for projects that link theory and practice, emphasize collaboration between university-based teacher educators and school partners, address key educational issues and support the principles of OISE's Initial Teacher Education program. The funded projects support university instructors in working with school partners to engage in professional inquiries related to curriculum design, instructional practice, teacher development, and student engagement. The projects frequently address underserved students or challenging issues needing further exploration in K-12 settings (e.g., English Language Learners in urban schools; culturally relevant and responsive pedagogy; early years' literacy development and social inclusion), and in the academic classes of the university instructors.

Core principles create the foundation for this professional learning model. Linking instructor, teacher and student learning to personal and institutional or system-wide goals (e.g., universities, schools, districts, Ministry of Education) has been a priority throughout the implementation of the initiative. For example, the most recent projects in the initiative examine different perspectives, practices, and possibilities in the design and enactment of inclusive curricula. The funded projects connect OISE's Initial Teacher Education program priorities (e.g., equity, diversity and social justice), the Ontario Ministry of Education's vision for inclusion and equity in today's classrooms (Ontario Ministry of Education, 2009a; 2009b), and specific school district-wide initiatives.

Additional core principles of the initiative center on collaborative inquiry and the need for current research to inform pedagogical practice:

Collaborative inquiry is a process consisting of repeated episodes of reflection and action through which a group of peers strives to answer a question of importance to them... (Heron 1996; Reason, 1988).

Indeed, the notion of co-inquiry doing research with people rather than on them is the defining principle of collaborative inquiry (Bray, Lee, Smith, \& Yorks, 2000, p.6-7). 
University and school-based educators work together in small teams to investigate authentic questions and use current research to inform meaningful practice in local schools and university classes. These teams have the responsibility for crafting the inquiry and collectively sharing their findings. In higher education contexts such inquiry would be characteristic of the Scholarship of Teaching and Learning (SoTL).

To date, eight themes have been explored in the Inquiry into Practice Series, with a total of 76 projects featured in the following publications (from most recent):

- Reaching every student through inclusive curriculum (Rolheiser, Evans \& Gambhir, 2011)

- School improvement and teacher education: Collaboration for change (Rolheiser, 2009a)

- Partnerships for professional learning: Literacy and numeracy initiatives (Rolheiser, 2009b)

- Initial teacher education: Enriching and extending partnerships (Rolheiser, 2008)

- School/university partnerships: Transforming teacher education (Rolheiser, 2007)

- School/university partnerships: Creative connections (Rolheiser, 2006)

- School/university partnerships: Innovations in teaching and learning (Rolheiser, 2005)

- School/university partnerships: Research into practice (Rolheiser, 2004)

In an effort to disseminate the work widely, a publication is released upon the completion of each round of funded projects, describing each project and highlighting key findings. The Inquiry Into Practice Series of publications has been provided to university instructors in OISE's teacher education program, schools, community organizations, visiting international delegations, and the broader public. The initiative and its specific projects have also been shared through professional presentations and conferences by university and school-based partners. An online version of the most recent publication, Inquiry into practice: Reaching every student through inclusive curriculum, has allowed broader dissemination of the perspectives, projects, and annotated resource list related to the theme:

http://www.oise.utoronto.ca/cms/oisefiles/ITE\%20 PUB\%202011_COMPLETE/HTML/index.html

\section{Challenges, Lessons Learned, and Outcomes}

In each yearly iteration of this initiative, there has been research on the initiative itself, influencing subsequent design. For the purpose of this current article we carried out an analysis of a variety of documents, including annual reviews of the implementation process, mid-year reports, and the final project reports of all eight thematic projects. Documents associated with each project were analyzed, providing nuanced understandings and empirical knowledge of both the content investigated and the processes involved in each initiative. Below is a brief overview of some of the challenges, lessons learned, and overall outcomes across all projects.

\section{Challenges}

Issues connected to the research design of individual projects, implementation, and funding are broad areas of challenge that have emerged in our study of this multi-year initiative.

We have found that some field participants need support with research design, for example, while others need support in connecting to a broader literature base, as they work with university instructors to prepare project proposals. While mentoring and coaching during proposal development has strengthened the final proposals these support mechanisms also necessitate more time in the development stage. Scaffolding is often needed in the design phase to move useful ideas into manageable and substantive projects. To address this challenge we provide support through one-on-one feedback, provision of models, and coaching to help 
refocus ideas and rework proposals.

Implementation issues have centered on the project timeline and initiative management. The short 9-month program cycle of OISE's postdegree consecutive teacher education program creates tight timelines. Yearly cycles overlap and it is often difficult for the researchers to move through ethical review processes, data collection, analysis and dissemination within the academic year. As the initiative has grown, a diverse leadership team has been needed to support implementation, including financial management, editorial support, and mentoring of novice researchers. Support is also needed to manage the tensions inherent in diverse partnerships within complex settings. Monitoring of project quality is an ongoing challenge throughout the implementation process.

As annual funding is dependent on external support, our leadership team has needed to constantly seek out sources. Given the varied grant sources over time, one of the challenges has been to align the project themes with grantee expectations and goals.

\section{Lessons learned}

The following seven lessons have emerged from our analysis of this professional learning initiative:

1. Even small grant amounts (initially only $\$ 2000 /$ project) provide an important incentive for university instructors and field partners to carry out their inquiries.

2. As the Series has progressed, we have found it increasingly important to connect the project themes to broader contextual and institutional priorities for relevance and dissemination (Fullan et al., 2006). Clearer links to our initial teacher education program principles has resulted in deepened commitment to these principles. By also connecting the yearly themes to provincial priorities we have been able to leverage additional funds and the research results have been disseminated more broadly.
3. Clarity and transparency of goals, timelines, and dissemination expectations for project leaders have strengthened outcomes and improved achievement of goals. Featuring and disseminating all projects through a final publication, sharing the publication at OISE's annual "Research Celebration," and subsequent dissemination of the publication to all OISE partner school districts, has motivated the project leaders and participants to meet timelines and has provided additional validation of their work.

4. Increasingly we have found that administrative supports are critical to the development and sustainability of the initiative. For example, facilitated update sessions have created a community of practice where participants share works in progress, problem solve, exchange successful strategies, and review interim reports. As the Series has progressed, dedicated support in the form of a project manager has ensured that teams are able to receive early feedback and regular communication throughout the various phases. The provision of report templates, writing guidelines, and project examples has improved the quality of proposals, ethics submission, and final reports.

5. Paying attention to project feasibility and transferability has been important. One-off events or projects that are too specific to be transferred to other contexts have not been funded. Seeing new ideas incorporated into ongoing curriculum and programming at both the university and school levels has validated the work of the participants and over time this has influenced knowledge building within our teacher education pro- 
gram and partner schools.

6. Continuous reflection and refinement of the overall conceptual framework of this initiative has been important. Regular monitoring of the selected themes and the inquiry process has been necessary in reflecting the dynamic and ever-changing contexts in which our programs work. To ensure the sustainability and manageability of individual projects and the overall initiative, the timeline was lengthened to a two-year project cycle for the most recently funded projects

7. The utilization of diverse teams with varied areas of expertise, disciplinary and research knowledge and skill sets has become increasingly important in the design of the various projects. As Lieberman (2011) asserts, relationships that build knowledge and bridge research and practice are "about being open to different ways of knowing." (p. 2). We have become better at capitalizing on existing trusting relationships between field and faculty partners to create projects and future collaborative inquiry opportunities.

\section{Outcomes}

A review of the projects, reported in the eight publications, revealed some important outcomes in three broad areas of change: institutional change, change in educational practice for university and school-based educators, and change experienced by learners.

\section{Institutional change}

This initiative has resulted in organizational benefits, including building stronger norms of collaborative inquiry, knowledge-building, and risk-taking as mechanisms for improvement. An important theme to all of these projects has been the importance of contextually responsive designs. As well, the ideas and pedagogical practices that have emerged from the funded projects have increasingly become embedded in our teacher education program (i.e., sustainability) and have contributed to instructional change and program improvement. An enhanced understanding and recognition of teacher education as a researchbased and evidence-informed endeavor has also heightened the status of initial teacher education within OISE and emphasized the importance of university-led teacher education programs. As the Inquiry Into Practice Series developed a history of success, it also led to additional funding for key priority areas by outside agencies (e.g., literacy and numeracy, inclusive curricula). We have also found that the snapshots of program development and innovation found in the eight publications have resulted in additional discussions of institutional change with educators from many locations locally and internationally. An additional institutional benefit is that the publications provide a partial history of curriculum and instructional change at OISE and in our partner schools and districts that can serve many additional purposes (e.g., documentation for program accreditation).

\section{Change in educational practice}

As noted by Wright (2010), one aspect of educational development that needs more research is "effective models for fostering teacher change" (p. 157). He also comments on the under- representation in the higher education literature regarding "collaborative initiatives among faculty, establishing values, practices, and habits of mind that are key to effective teaching within communities of pedagogues" (p. 160). Evidence from this current study using collaborative inquiry as a model supporting teacher change reveals a range of innovative approaches to teacher learning, as well as changes in classroom practices in schools (e.g., a support group for culturally relevant and responsive teaching) and in our university teacher education program (e.g., the use of lesson study). As well, changes in educational practice have contributed to the broader knowledge base in teacher education and in K-12 education. For example, teams regularly share project processes and products through professional and academic conferences, academic journals and books, and practitioner professional resources. Additionally, a number of the projects have led to 
the development of further proposals for larger-scale research grants, continuing the cycle of supporting changes in educational practice. Two of the most significant shifts have been the deprivatization of practice and the emergence of professional learning models that are focused on communities of practice in elementary, secondary and higher education, as opposed to a reliance on individualistic attempts to change practice.

\section{Change experienced by learners}

The ultimate goal of our collective work is to enhance learning. Review of the 76 project reports provides substantial evidence of deepened learning for students, teacher candidates, university instructors and K-12 educators. For example, our field partners (e.g., principals, teachers) have enhanced their knowledge, skills and attitudes about teacher education, while university instructors have enhanced their instructional practices as well as their understanding of educational improvement processes. Teacher candidates have also experienced the power of partnership in transforming schools and universities, which has influenced their orientations to collaborative inquiry. The diverse teams have come to value co-learning so strongly that many have continued their collaborative work or made commitments to collaborating in the future.

\section{Reflections and Next Steps}

Responding to shifting curricular and instructional priorities and issues in universities and school systems is complicated and requires new ways of thinking about learning and teaching. Through the initiative we have described in this article we have learned that the design and implementation of effective professional learning for university instructors and for field-based partners (in our case, $\mathrm{K}-12$ educators) is iterative and requires attention to a myriad of factors. Deliberate, ongoing, relevant professional learning and support for university instructors and field educators is essential in efforts to improve student learning and reform schools and teacher education programs. We also believe that many of the features of our model can be transferred to other university-field contexts where collaborative inquiry and inquiry into practice would be advantageous.

The limitations of traditional forms of professional learning to support teacher development and enhance student learning in higher education and K-12 education are clear and have been well documented in the literature, along with descriptions of emergent models of professional learning that are more powerful (Knapper, 2010; Learning Forward, 2011; Wright, 2010). The collaborative inquiry model described in this article was designed by our leadership team to support more powerful models of teacher learning. Our ultimate goal in putting this initiative in place was to enhance both teaching and learning. Knapper (2010), in his study of excellent teaching departments in 11 research-intensive universities worldwide, notes that "the results show how good teaching can be encouraged and led, despite formidable barriers to embedding change" (p. 229). His discussion includes a description of the important role that academic leaders in higher education play in supporting effective teaching, a finding that we also believe was a critical factor in the success of the initiative described here. Knapper's (2010) comments include:

...leadership that is knowledgeable about pedagogical issues, articulates a convincing rationale for change, supports colleagues and students who can help transform teaching and learning practice, gathers evidence for the effectiveness of new approaches, and ensures that teaching achievements are recognized across the institution and beyond. (p. 241)

Professional learning models and practices need to be respectful of the complexity and multifaceted nature of teaching, what we might refer to as "teaching with deep understanding" (Rolheiser \& Evans, 2006). Our use of a collaborative inquiry model is also based on our belief that teachers in higher education and K-12 education care deeply about getting better at teaching to better support learners and learning. As 
such, our approach has been grounded in the belief that we are working with highly competent teacher educators and teachers who will continue to learn, be adaptive, build a sophisticated pedagogical repertoire, integrate different kinds of knowledge and apply emerging research for varying purposes.

While a workable timeline, and administrative and resource supports are foundational requirements for our ongoing work in this professional learning initiative, we believe sustainable models need to go beyond logistics to include a linking of professional development to student learning and professional standards for learning, connections to larger systems, the incorporation of a range of jobembedded professional learning approaches (such as collaborative inquiry), and the use of evidence-based knowledge to inform practice.

As leaders of the Inquiry Into Practice Series, we have found that there is a critical need for our own ongoing reflection and planning in relation to the processes, practices and products of this initiative. The real strength of our collective work and collaborative inquiry has been the range of new evidence-based practices being carried out in both $\mathrm{K}-12$ and university classrooms.

Central to our findings is the value of and need for schools, communities, school districts, and universities to work as teams and learn collaboratively. There are many compelling theoretical and practical reasons for sustained field-university partnerships. As Lieberman (2011) states, "there are few avenues where researchers, policy makers and practitioners actually communicate across cultures" (p. 1). This initiative has encouraged communication and bridging of differing areas of expertise and knowledge in the service of learning for students, teacher candidates, teachers, teacher educators, and researchers. The outcomes of this initiative reinforce our commitment to collaborative inquiry and the institutional infrastructure and leadership that make such inquiry possible (Justice, et al., 2009).

\section{References}

Berliner, D.C. (2005). The near impossibility of testing for teacher quality. Journal of Teacher Education, 56(3), 205-213.

Bransford, J., Darling-Hammond, L. \& LePage, P. (2005). Introduction. In L. DarlingHammond \& J. Bransford (Eds.), Preparing teachers for a changing world: What teachers should learn and be able to do. San Francisco: Jossey-Bass.

Bray, J.N., Lee, J., Smith, L.L., \& Yorks, L. (2000). Collaborative inquiry in practice, action, reflection, and making meaning. Thousand Oaks, CA: Sage.

Broad, K. \& Evans, M. (2006). A review of literature on professional development content and delivery modes for experienced teachers. Technical Report. Toronto, ON: Ontario Ministry of Education.

Feiman-Nemser, S. (2001). From preparation to practice: Designing a continuum to strengthen and sustain teaching. Teachers College Record, 103(6), 1013-1055.

Fullan, M. (1991). Professional development of educators. In M. Fullan, The new meaning of educational change (pp. 315-344). New York: Teachers College Press.

Fullan, M., Hill, P., \& Crevola, C. (2006). Breakthrough. Thousand Oaks, CA: Corwin Press.

Gopinathan, S., Tan, S., Yan Ping, F., Devi, L., Ramos, C., \& Chao, E. (2008). Transforming 21st century teacher education through redefined professionalism, alternative pathways and genuine partnerships. A report commissioned by The International Alliance of Leading Education Institutes. Singapore: The National Institute of Education, Nanyang Technological University.

Halliwell, J. (2008). The nexus of teaching and research: 
Evidence and insights from the literature. Toronto: Higher Education Quality Council of Ontario.

Heron, J. (1996). Cooperative inquiry: Research into the human condition. London: Sage.

Justice, C., Rice, J., Roy, D., Hudspith, B., \& Jenkins, H. (2009). Inquiry-based learning in higher education: Administrators' perspectives on integrating inquiry pedagogy into the curriculum. Higher Education, 58(6), 841855.

Knapper, C. (2010). Changing teaching practice: Barriers and strategies. Chapter in Christenson Hughes, J. \& Mighty, J. (Eds.), Taking stock: Research on teaching and learning in higher education, pp. 229-242. Kingston, ON: School of Policy Studies, Queen's University.

Knight, J. (2011). Unmistakable impact: A partnership approach for dramatically improving instruction. Thousand Oaks, CA: Corwin, SAGE \& Learning Forward.

Learning Forward. (2011). Standards for professional learning. Oxford, $\mathrm{OH}$ : Author.

Lieberman, A. (2011). Lead the change series. AERA Educational Change Special Interest Group, (2). Retrieved from http://www.aera.net/ Educational Change SIG.htm

Lieberman, J. \& Wilkins, E. (2006). The professional development pathways model: From policy to practice. Kappa Delta Pi Record, 42(3), 124.

Ontario Ministry of Education. (2009a). Equity and inclusive education in Ontario schools: Guidelines for policy development and implementation. Toronto: Author.

Ontario Ministry of Education. (2009b). Realizing the promise of diversity: Ontario's equity and inclusive education strategy. Toronto: Author.

Ramsden, P. (2003). Learning to teach in higher education. New York: Routledge Falmer.

Reason, P. (1988). Human inquiry in action: Developments in new paradigm research. Newbury Park: Sage.

Rolheiser, C. (Ed). (2009a). School improvement and teacher education: Collaboration for change. Toronto, ON: OISE Initial Teacher Education Program.

Rolheiser, C. (Ed). (2009b). Partnerships for professional learning: Literacy and numeracy initiatives. Toronto, ON: OISE Initial Teacher Education Program.

Rolheiser, C. (Ed). (2008). Initial teacher education: Enriching and extending partnerships. Toronto, ON: OISE/UT Teacher Education Program.

Rolheiser, C. (Ed). (2007). Schoolluniversity partnerships: Transforming teacher education. Toronto, ON: OISE Teacher Education Program.

Rolheiser, C. (Ed). (2006). School/university partnerships: Creative connections. Toronto, ON: OISE/UT Teacher Education Program.

Rolheiser, C. (Ed). (2005). School/university partnerships: Innovations in teaching and learning. Toronto, ON: OISE/UT Teacher Education Program.

Rolheiser, C. (Ed). (2004). School/university partnerships: Research into practice. Toronto, ON: OISE/UT Teacher Education Program.

Rolheiser, C. \& Evans, M. (2006). Teaching for depth in teacher education. In K. Leithwood, P. McAdie, N. Bascia, \& A. Rodrigue (Eds.), Teaching for deep understanding: What 
every educator should know (pp. 165-174). Thousand Oaks, CA: Corwin Press.

Rolheiser, C., Evans, M., \& Gambhir, M. (Eds). (2011). Inquiry into practice: Reaching every student through inclusive curriculum. Toronto, ON: OISE Initial Teacher Education Program.

Turner-Bisset, R. (2001). Expert teaching: Knowledge and pedagogy to lead the profession. London: David Fulton Publishers.

Wright, W.A. (2010). Mind the gap: Aligning research and practice in teaching, learning, and educational development. In J. Christenson Hughes \& J. Mighty (Eds.), Taking stock: Research on teaching and learning in higher education (pp. 155-165). Kingston, ON: School of Policy Studies, Queen's University.

\section{Biographies}

Carol Rolheiser is director, Centre for Teaching Support \& Innovation at the University of Toronto, the former associate dean of Teacher Education at the Ontario Institute for Studies in Education (OISE), and a professor in the Department of Curriculum, Teaching and Learning at OISE. Her research focuses on teacher education/development, teaching in higher education, instructional and assessment innovation, school improvement, leadership, system reform, and managing educational change.

Mark Evans is the former associate dean of Teacher Education and a professor in the Department of Curriculum, Teaching and Learning at OISE. Mark's current research focuses on international dimensions of teacher education, educating for global citizenship, and inclusive curriculum and instructional practices in schooling contexts. Mark has been involved in a variety of curriculum reform initiatives and teacher education projects, locally and internationally.

Mira Gambhir is currently a sessional lecturer in the
Master of Teaching program at the Ontario Institute for Studies in Education. Her areas of research interests include: diversity education; inclusion; teacher education program design; and comparative international education.

Kathy Broad is the Academic Director, Initial Teacher Education at OISE. Her teaching and research interests include: teacher education; aboriginal teacher education; inclusive and differentiated pedagogical practice; and educational leadership. 